\title{
Splitting Time
}

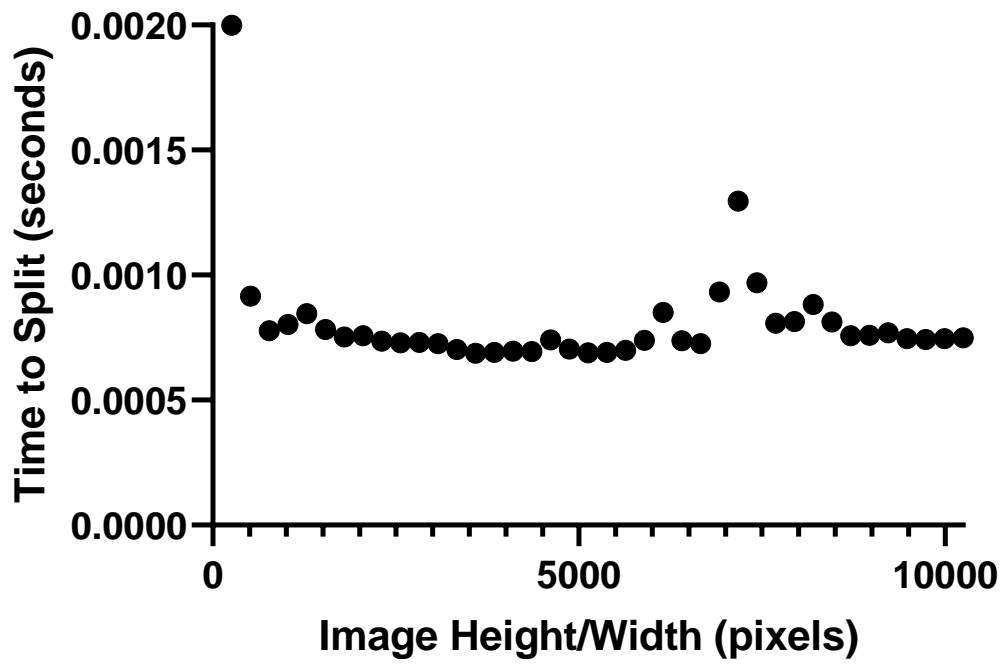

